\title{
The influence of biodiesel composition on compression ignition combustion \\ and emissions
}

\author{
Paul Hellier*a and Nicos Ladommatos ${ }^{\mathrm{a}}$
}

${ }^{a}$ Department of Mechanical Engineering, University College London, Torrington Place, London WC1E 7JE, United Kingdom

*Corresponding author:

Dr Paul Hellier

University College London, Department of Mechanical Engineering

Roberts Building, Torrington Place

London, WC1E 7JE, UK

p.hellier@ucl.ac.uk

Short title: Influence of biodiesel composition on combustion and emissions

\begin{abstract}
$\underline{\text { Abstract }}$
Renewable alternatives to fossil fuels are necessary for the reduction of anthropogenic greenhouse gas emissions, the increased atmospheric concentrations of which are resulting in global climate change. Biodiesel, fatty acid esters prepared from the reaction of triglycerides with alcohols, is a potentially sustainable fuel for compression ignition combustion, and is already widely used to displace fossil-derived diesels. However, there is a wide range of potential feedstocks suitable for the production of biodiesel, and the composition of these oils and alcohols can have a significant impact on the combustion characteristics of the resultant biodiesel. Therefore, this paper presents a review of biodiesel composition from various
\end{abstract}


sources, and the effects of differing composition on combustion phasing and the emissions of regulated pollutants, NOx and particulate matter, in compression ignition engines. The primary influence of biodiesel composition on fuel ignition delay is through the fatty acid alkyl moiety, with either an increase in alkyl chain length or degree of saturation reducing the duration of ignition delay. NOx emissions levels are determined through in-cylinder temperature conditions, most strongly influenced in common rail injection systems by the duration of ignition delay and in mechanical injection systems by injection timing, which advances with increasing biodiesel bulk modulus. Emissions of particulate matter increase with biodiesel physical properties, such as boiling point or viscosity, which increase with both increasing fatty acid moiety and alcohol moiety chain length.

Keywords: biodiesel, compression ignition combustion, NOx, soot, molecular structure, ignition delay.

\section{Introduction}

There is now consensus and acceptance that the continued use of fossil fuels to meet the majority of global energy demand (approximately $86 \%$ in $2012^{1}$ ) is unsustainable and likely to result in catastrophic climate change ${ }^{2}$. Where such concerns were once accompanied by those regarding the imminent depletion of fossil fuel reserves ${ }^{3}$, there is now growing realisation that a significant portion of such remaining reserves should in fact not be utilised if necessary reductions in anthropogenic emissions of greenhouse gases (GHG) are to be achieved ${ }^{4,5}$. Such factors have driven legislative requirements for the displacement of fossil fuels with sustainable alternatives; for example the 2009 European Parliament Renewable Energy Directive, which stipulates that a minimum $10 \%$ of gasoline and diesel fuels for road transport in all EU member states must be from renewable sources by $2020^{6}$. 
Biodiesel is the most widely considered alternative to fossil diesel for compression ignition combustion, and is commonly produced from the reaction of vegetable (or animal) oils with an alcohol, in a reaction known as transesterification. While the idea of vegetable oils as fuels for compression ignition engines has been in place for over a century (for example the widely cited demonstration by Rudolph Diesel of a compression ignition engine operating on peanut oil in 1900), it was not until the early 1980's that a concerted effort was made to utilise such fuels for displacement of fossil-derived diesel.

Initial testing of straight vegetable oils for compression ignition combustion (predominantly from sources such as rapeseed, soybean and sunflower, and in medium-duty tractor engines ${ }^{7,8}$ ) observed several issues with the use of such fuels detrimental to engine performance. These included fuel injector coking, combustion chamber deposits, piston ring sticking, thickening and dilution of engine lubrication oil ${ }^{8,9}$, however, subsequent investigations quickly identified that these problems could be reduced in severity through transesterification of the vegetable oils to fatty acid esters (biodiesel) ${ }^{10,11}$. 

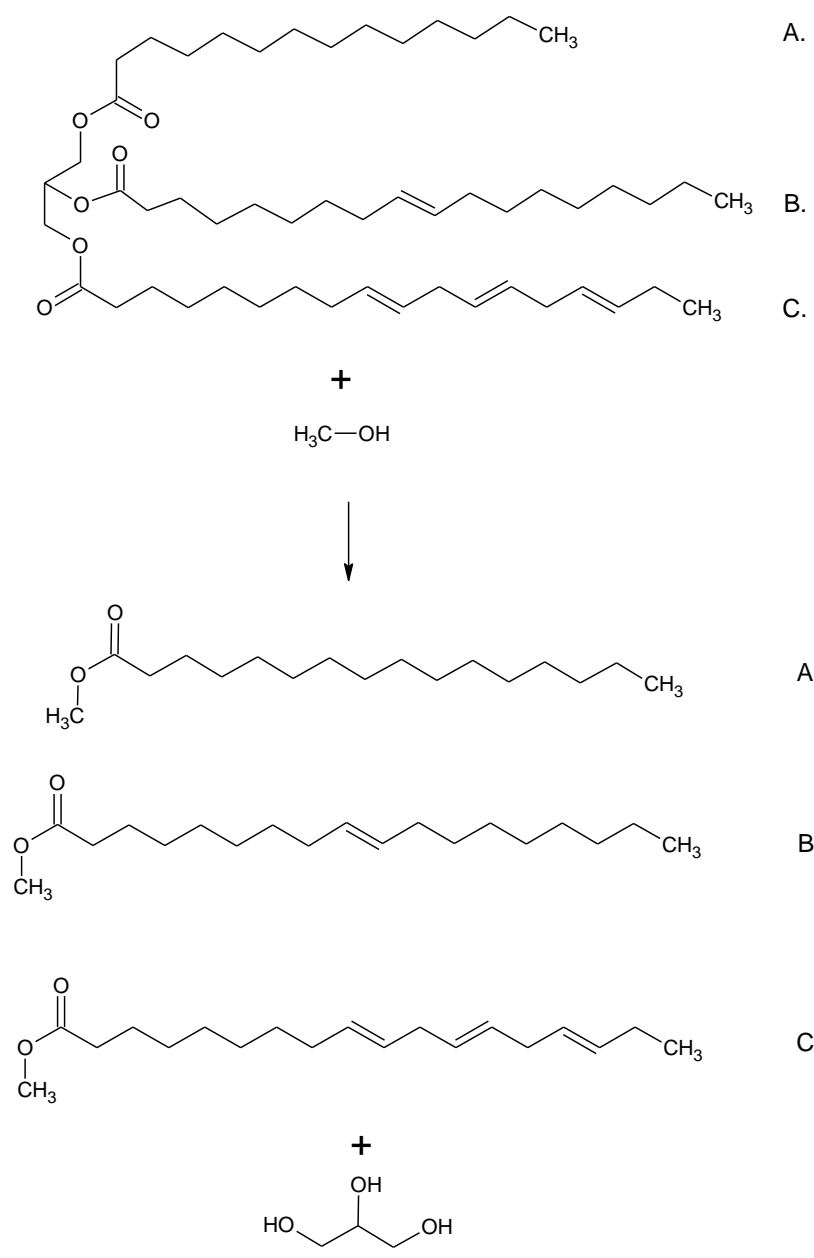

Figure 1 - Transesterifaction of a typical vegetable oil triglyceride to FAME with preservation of the fatty acid alkyl chain length and degree of saturation, (a) C16:0, (b) C18:1, and (c) C18:3.

Figure 1 shows the transesterification of a typical vegetable oil triglyceride with methanol to form three fatty acid methyl esters (FAME) and one molecule of glycerol. Triglycerides are comprised of three naturally esterified fatty acid alkyl chains (highlighted as A, B and C in Figure 1) which are typically of straight carbon chain lengths of between 16 and 18 carbon atoms long ${ }^{12}$, and range from being fully saturated to containing four double bonds between carbon atoms. As shown in Figure 1, formation of fatty acid esters from triglycerides and short chain alcohols (transesterification) results from the substitution of triglyceride fatty acid alkyl 
chains with $\mathrm{OH}$ groups from an alcohol (to form glycerol), while the alkyl moiety of the alcohol bonds to the terminal oxygen of the fatty acid (to form a fatty acid ester).

The choice of transesterification reaction conditions and catalyst are dependent on the composition of vegetable oil feedstock, though currently the most common method employed in the industrial production of biodiesel is the use of a homogenous (reaction mixture and catalyst both liquid) alkali catalyst, such as sodium hydroxide or potassium hydroxide ${ }^{13}$. Alkali catalysts are not suitable for oils containing free fatty acids (fatty acids with are not attached to a triglyceride or diglyceride) in excess of $0.5 \mathrm{wt} \%$, as subsequent formation of soaps from the free fatty acids increases the solubility of esters in glycerol, impeding the product separation ${ }^{14}$. Methanol is the most often used alcohol for the process of transesterification, however, production from longer chained alcohols, such as ethanol, propanol and butanol is also possible, though alkali catalyzed transesterification is generally unsuitable for use with longer chained alcohols ${ }^{11}$. However, there are alternative methods of transesterification for which long chain alcohols are superior to methanol, such as transesterification at supercritical conditions, which allows the reaction to occur in the absence of a catalyst, resulting in a high purity of both products and excess reactants ${ }^{15,16}$.

While at present, biodiesel production from crop-derived feedstock satisfies the sustainability requirements of the European Parliament Renewable Energy Directive ${ }^{17}$, there is growing concern that production and use of such fuels may not offer significant reductions in net emissions of GHG, relative to the use of fossil fuels, over the whole of the fuel production-toconsumption lifecycle ${ }^{18}$. A proposed strengthening of the directive, taking these concerns into consideration through quantification of impacts arising from indirect land use changes, would see the level of renewable fuels from food crops, such as vegetable oils, capped at $5 \%$ of road transport fuels ${ }^{19}$. The remaining $5 \%$ would then necessarily be sourced from feedstocks such as photosynthetic micro-organisms, lignocellulosic biomass, and various waste streams with 
lower net GHG emissions. Identifying genuinely sustainable feedstocks available in significant quantities is therefore a major challenge to the continued production and use of biodiesel to displace fossil-derived diesel.

In addition, there are a number of further technical challenges related to the composition of the oils used for biodiesel production, both in the processing of such fuels and their use in modern compression ignition engines. The presence of free fatty acids complicates the transesterification process, while the degree of fatty acid ester saturation has implications for the oxidative stability of biofuels. Increasing fatty acid ester alkyl chain unsaturation has been observed to coincide with a decrease in oxidative stability, with the products of fatty acid methyl ester oxidation, which are primarily acids and other short to long chain oxygenated compounds, negatively impacting on engine performance and durability in a manner similar to straight vegetable oils ${ }^{20,21}$. Meanwhile, both the physical properties and molecular structures of fatty acid esters used for biodiesel impact on the efficiency of combustion in compression ignition engines and the emission of regulated pollutants, such as nitrogen oxides (NOx) and particulate matter $(\mathrm{PM})$.

Many studies of biodiesel have focused on the performance of these fuels from various sources relative to existing fossil diesel fuels, and several extensive reviews have been presented on the subject $\mathrm{t}^{11,22-27}$. However, in the context of a legislative and environmental requirement to identify new sustainable sources of oils for biodiesel production, understanding how the composition and physical properties of these oils impacts on energy release and emissions characteristics in compression ignition combustion can be valuable for the screening of potential new sources of oils. Therefore, this paper presents a brief review of the various potential sources of oils for biodiesel, and the composition and physical properties of these oils. The effect of these chemical and physical properties on combustion and emissions 
characteristics is then reviewed, with particular emphasis on the influence of fatty acid ester molecular structure on combustion phasing and the subsequent formation of exhaust emissions.

\section{Sources of fatty acids for biodiesel production}

Among the first crops to be considered for biodiesel production were sunflower, rapeseed and soybean oil ${ }^{28}$, and these three now dominate crop production for biodiesel in the European Union, with the largest land use for rapeseed, sunflower and a smaller proportion for soybean ${ }^{29}$. Other edible oils from agricultural crops that are commonly considered include corn ${ }^{27,30}$, cottonseed $^{31}$, palm $^{16,32}$ and peanut ${ }^{33,34}$. 
Table 1 - Fatty acid profiles of various and edible oils and non-edible oils ${ }^{30,35-38}$.

\begin{tabular}{|c|c|c|c|c|c|c|c|c|c|c|c|c|c|c|c|c|c|}
\hline & \multirow{2}{*}{ Oil } & \multicolumn{16}{|c|}{ Fatty acid composition (wt.\%) } \\
\hline & & C 8:0 & C10:0 & C12:0 & C14:0 & C16:0 & C16:1 & C18:0 & C18:1 & C18:2 & C18:3 & C18:4 & $\mathrm{C} 20: 0$ & $\mathrm{C} 20: 1$ & C22:0 & C24:0 & Other \\
\hline \multirow{11}{*}{ Edible $^{30}$} & Cottonseed & - & - & - & 0 & 28.35 & - & 0.95 & 13 & 57.7 & 0 & - & - & - & - & - & - \\
\hline & Rapeseed & - & - & - & 0 & 3.25 & - & 0.95 & 64.05 & 22.15 & 8.1 & - & - & - & - & - & - \\
\hline & Safflower & - & - & - & 0 & 9 & - & 2 & 12 & 78 & 0 & - & - & - & - & - & - \\
\hline & Sunflower & - & - & - & 0 & 6.2 & 0.1 & 2.95 & 17.35 & 73.45 & 0 & - & - & - & - & - & - \\
\hline & Palm & - & - & - & - & 42.6 & 0.3 & 4.4 & 40.5 & 10.1 & 0.2 & 1.1 & - & - & - & - & - \\
\hline & Corn & - & - & - & 0 & 12 & - & 2 & 25 & 6 & $\mathrm{Tr}$ & - & $\mathrm{Tr}$ & - & - & - & - \\
\hline & Tallow & - & - & - & - & 23.3 & 0.1 & 19.3 & 42.4 & 2.9 & 0.9 & 2.9 & - & - & - & - & - \\
\hline & Soybean & - & - & - & - & 13.9 & 0.3 & 2.1 & 23.2 & 56.2 & 4.3 & 0 & - & - & - & - & - \\
\hline & Peanut & - & - & - & 0 & 11 & - & 2 & 48 & 32 & 1 & - & 1 & - & 2 & 1 & - \\
\hline & Coconut & 8.9 & 6.2 & 48.8 & 19.9 & 7.8 & 0.1 & 3 & 4.4 & 0.8 & 0 & 65.7 & - & - & - & & - \\
\hline & Castor & & & - & - & 1.1 & 0 & 3.1 & $4.9+89.6$ ricinoic acid & 1.3 & 0 & - & - & - & - & - & - \\
\hline \multirow{7}{*}{ Non-edible } & $\begin{array}{c}\text { Jatropha curcas } \\
\text { L. }{ }^{35}\end{array}$ & - & - & - & 1.4 & 14.15 & 0.7 & 7.6 & 39.95 & 36.85 & 0.2 & - & 0.3 & - & - & - & - \\
\hline & Pongamia ${ }^{35}$ & - & - & - & - & 10.6 & - & 6.8 & 49.4 & 19 & - & - & 4.1 & 2.4 & 5.3 & 2.4 & - \\
\hline & Rice brand ${ }^{35}$ & - & - & - & 0.3 & 12.5 & - & 2.1 & 47.5 & 35.4 & 1.1 & - & 0.6 & - & 0.3 & 0.2 & - \\
\hline & Tobacco $^{30}$ & - & - & - & 0.13 & 9.915 & 0.1 & 3.415 & 13.47 & 68.62 & 2.445 & - & - & - & - & - & 0.69 \\
\hline & Micro-algae $^{36}$ & - & - & - & - & 51 & - & 2 & 39 & 7 & - & - & & & & & 1 \\
\hline & Fungus ${ }^{37}$ & - & - & - & 0.8 & 20 & 2.3 & 2 & 37 & 14.3 & 18.5 & - & 0.2 & 0.59 & 0.5 & 1.2 & 10 \\
\hline & $\begin{array}{c}\text { Oleaginous } \\
\text { yeasts }(Y . \\
\text { lipolytica })^{38}\end{array}$ & - & - & - & - & 11 & 5 & 9 & 55 & 10 & - & - & - & - & - & - & - \\
\hline
\end{tabular}


Table 1 shows the fatty acid profiles of both edible and non-edible oils currently used or considered for biodiesel production. Interesting to note, is the variation in the fatty acid profile of the three most widely used oils, with both sunflower and soybean composed of significantly higher levels of C18:2 (referring to a fatty acid of alkyl chain length 18 and with two double bonds within the fatty acid alkyl chain) fatty acids, while rapeseed oil has appreciably higher levels of more saturated C18:1 fatty acids (Table 1). It can also be seen that other oils, such as palm or tallow, have higher levels of shorter more saturated fatty acids, such as C16:0 (Table 1).

Concerns as to the strain on global food supplies due to the diversion of agricultural land for biofuel crops has led to much investigation into new potential sources of fatty acids. Sources such as jatropha ${ }^{39}$, coconuts ${ }^{40}$ and tobacco seeds ${ }^{41}$ have been considered, and many studies 30,42,43 have assessed the viability and sustainability of such feed-stocks. A further important source of oils for biodiesel production are waste streams. Several studies have considered the use of waste cooking oils ${ }^{44,45}$, and oils extracted from other waste sources, such as used coffee grounds ${ }^{46}$, are also increasingly investigated.

However, one non-food crop source of oils that that differs significantly in nature and has garnered particular interest of late are micro-organisms, such as micro-algae, which naturally produce and accumulate triglycerides within cell membranes ${ }^{47}$. Micro-organisms are an attractive potential source because they do not require agricultural grade land to be cultivated, and can have a low resource requirement when growing; for example photosynthetic microalgae can grow on sunlight and atmospheric carbon dioxide ${ }^{48}$ and fungi on glycerol from biodiesel production ${ }^{37}$. Table 1 shows the fatty acid profile of oils from micro-algae ${ }^{36}$, oleaginous fungi ${ }^{37}$ and oleaginous yeast ${ }^{38}$. Notwithstanding the variability of micro-organism fatty acid profiles with strain and species ${ }^{38,49}$, it can be seen that the majority of oils from these 
micro-organisms are in the range of $\mathrm{C} 16: 0$ to $\mathrm{C} 18: 2$ and are not dissimilar to those currently in commercial use for biodiesel production (Table 1).

\section{Effects of biodiesel composition on combustion phasing}

\subsection{Fatty acid moiety}

Table 2 - Physical properties of FAME produced from various edible and non-edible oils, adapted from compilation by Leung et al. ${ }^{13}$ with permission from Elsevier.

\begin{tabular}{|c|c|c|c|c|c|c|c|}
\hline $\begin{array}{l}\text { Oil utilised in FAME } \\
\text { production' }\end{array}$ & $\begin{array}{l}\text { Kinematic } \\
\text { viscosity } \\
\text { (cst at } 40 \\
{ }^{\circ} \mathrm{C} \text { ) }\end{array}$ & Density $\left(\mathrm{g} / \mathrm{cm}^{3}\right)$ & $\begin{array}{c}\text { Saponification } \\
\text { number }\end{array}$ & $\begin{array}{l}\text { Iodine } \\
\text { value }\end{array}$ & $\begin{array}{l}\text { Acid value } \\
\qquad(\mathrm{mg} \\
\mathrm{KOH} / \mathrm{g})\end{array}$ & $\begin{array}{l}\text { Cetane } \\
\text { number }\end{array}$ & $\begin{array}{l}\text { Heating } \\
\text { value } \\
(\mathrm{MJ} / \mathrm{kg})\end{array}$ \\
\hline Soybean & 4.08 & 0.885 & 201 & 138.7 & 0.15 & 52 & 40 \\
\hline Rapeseed & $4.3-5.83$ & $0.88-0.888$ & - & - & $0.25-0.45$ & $49-50$ & 45 \\
\hline Sunflower & 4.9 & 0.88 & 200 & 142.7 & 0.24 & 49 & 45.3 \\
\hline Palm & 4.42 & $0.86-0.9$ & 207 & 60.07 & 0.08 & 62 & 34 \\
\hline Peanut & 4.42 & 0.883 & 200 & 67.45 & - & 54 & 40.1 \\
\hline Corn & 3.39 & $0.88-0.89$ & 202 & 120.3 & - & $58-59$ & 45 \\
\hline Canola & 3.53 & $0.88-0.9$ & 182 & 103.8 & - & 56 & 45 \\
\hline Cotton & 4.07 & 0.875 & 204 & 104.7 & 0.16 & 54 & 45 \\
\hline Jatropha curcas & 4.78 & 0.8636 & 202 & 108.4 & 0.496 & $61-63$ & $40-42$ \\
\hline Pongamina pinnata & 4.8 & 0.883 & - & - & 0.62 & $60-61$ & 42 \\
\hline Tallow & - & 0.856 & 244.5 & 126 & 0.65 & 59 & - \\
\hline
\end{tabular}

While biodiesels have generally been found to exhibit a higher cetane number and shorter duration of ignition delay (the interval between fuel injection and autoignition) than fossil diesels $^{50}$, various studies have also observed a correlation between FAME cetane number and fatty acid composition ${ }^{10,51}$. In particular, a decrease in the duration of ignition delay with an increase in either fatty acid alkyl chain length or degree of saturation ${ }^{52-56}$, and a concurrent 
decrease in peak heat release rates with a decrease in ignition delay through either an increased fatty acid alkyl chain length or degree of saturation has also been observed ${ }^{52}$. This can be attributed to a reduced duration available for fuel and air mixing between fuel injection and the start of combustion, which results in a smaller premixed burn fraction, and a more gradual release of energy during a greater diffusion (or mixing controlled) combustion fraction ${ }^{57}$. Table 2 (adapted from Leung et al. ${ }^{13}$ ) shows the physical properties, including cetane number, of fatty acid methyl esters (FAME) produced from various edible and non-edible oils. From Table 2, it can be seen that palm oil produces a FAME of relatively high cetane number, 62, and sunflower oil that with a relatively low cetane number, 49 , and in this coincides with a higher fraction of more saturated fatty acids (C16:0 and C18:1) present in palm oil relative to sunflower oil (Table $1)$.

In engine tests of palm oil FAME and linseed oil FAME, Benjuma et al. ${ }^{54}$ observed an appreciably longer duration of ignition delay of the highly unsaturated linseed oil FAME relative to the more saturated palm oil FAME, with a 1:1 blend of the palm oil FAME and linseed oil FAME displaying an ignition delay between that of the two FAMEs. Schönborn et al. ${ }^{52}$, in engine tests conducted with pure single component fatty acid esters, observed a linear decrease in the duration of ignition when increasing fatty acid saturated alkyl chain length from 12 to 22 (C12:0 to $\mathrm{C} 22: 0)$.

Zhang et al. ${ }^{55}$ investigated the influence of fatty acid ester molecular structure on ignition kinetics in a motored cooperative fuels research (CFR) engine at very low loads with constant equivalence ratio. The influence on double bond position within the fatty acid alkyl chain was studied by considering three esters with fatty acid alkyl chain length of 9 , methyl nonanoate (C9:0), methyl 2-nonenoate (C9:1) and methyl 3-nonenoate (C9:1). The effect of introducing a double bond into the fatty acid chain length was to greatly reduce the onset and magnitude of the low temperature heat release (and thus the duration of ignition delay) relative to the 
equivalent fully saturated ester (methyl 2-nonenoate relative to methyl nonanoate). Moving the double bond towards the centre of the fatty acid chain length further delayed the onset of the low temperature heat release rate and decreased its magnitude (methyl 3-nonenoate relative to methyl 2-nonenoate). The movement of the double bond towards the centre of fatty acid moiety was suggested to be an increasingly inhibiting influence on ignition quality due to the limitations that the position of the double bond placed on the formation of six and seven membered transition rings.
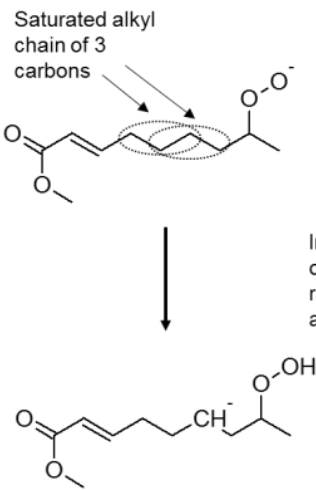

b.

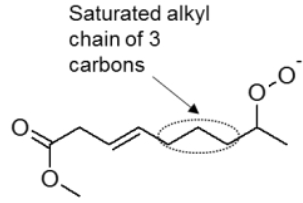

Internal isomerisation of alkyl chain peroxy

radicals to peroxy

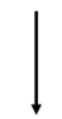<smiles>COC(=O)C/C=C/CC(C)OO</smiles>

Figure 2 - Internal isomerisation of (a) methyl 2-nonenoate and (b) methyl 3-nonenoate peroxy radicals saturated carbons available for formation of transition rings circled in dotted lines.

Such transition rings are necessary for the isomerisation of alkyl chain peroxy radicals to peroxy alkyl structures, which is a key stage in the fuel breakdown and branching reactions that produce the radicals and escalating temperatures necessary for autoignition in compression ignition combustion ${ }^{55,58}$. Figure 2 shows the internal isomerisation of methyl 2-nonenoate and methyl 3-nonenoate peroxy radicals to peroxy alkyl chains. The formation of six or seven membered transition rings requires a fully saturated alky chain of at least three carbon atoms ${ }^{59}$, and it can be seen that movement of the double bond from methyl 2-nonenoate (Figure 2a) to methyl 3-nonenoate (Figure 2b) reduces the longest fully saturated alkyl chain length from four 
to three carbon atoms, thereby reducing the potential for formation of transition rings. Zhang et al. ${ }^{55}$ also undertook exhaust sampling and gas chromatography identification of the species therein, and from the intermediates observed it was concluded that esters with fully saturated fatty acid alkyl chains followed very similar reaction pathways to $n$-alkanes, while those containing a double bond in the fatty acid moiety appeared to be reacting along the same routes as olefins under similar conditions.

\subsection{Alcohol moiety}

While the production of fatty acid esters from alcohols other than methanol is viable, the impact of varying ester alcohol moiety on combustion and emissions has received far less attention than that of the fatty acid moiety. Cetane number measurements of methyl, ethyl, propyl and butyl esters of various alkyl chain lengths and degree of saturation found that butyl esters consistently possessed a cetane number higher than those prepared with shorter chain alcohols, however, no linear trend between cetane number and alcohol carbon chain length is apparent $^{60,61}$. Engine testing of fatty acids esters of varying alcohol moiety have generally found no discernible difference ${ }^{44}$ or only a slight increase in the ignition quality of ethyl esters relative to equivalent methyl esters ${ }^{52}$. In engine tests of single component esters produced from various straight and branched short chained alcohols (methanol to tert-butanol), Hellier et al. ${ }^{62}$ found an observable increase in the duration of ignition delay relative to the equivalent FAME (methyl stearate) only in the case of the ester with the most branched alcohol moiety (tert-butyl stearate). Other studies of esters with branched alcohol moieties have either found no change in ignition quality ${ }^{63}$, or a slight increase in the duration of ignition delay in the case of the most branched alcohol moiety ${ }^{56,64}$. 
In engine tests with a CFR engine, Zhang and Boehman ${ }^{56}$ also found that increasing the alcohol moiety chain length while keeping the fatty acid chain length constant, methyl nonanoate (C9:0) to ethyl nonanoate (C9:0), reduced the duration of ignition delay of the ester. This was attributed to a combination of an increase in the number of easily abstracted secondary $\mathrm{C}-\mathrm{H}$ bonds when increasing the alcohol chain length, and the suggested potential of ethyl esters to undergo a six centred uni-molecular elimination reaction, which has relatively low activation energy and initiates fuel breakdown without the need for any radical addition or external hydrogen abstraction. When the total number of carbon atoms in the ester was held constant and the alcohol chain length increased, methyl heptanoate (C9:0) to ethyl hexanoate (C8:0), the duration of ignition delay was observed to increase, highlighting the greater importance to ester ignition quality of the fatty acid alkyl chain length relative to the alcohol moiety chain length. 


\section{Effects of biodiesel composition on exhaust emissions}

\subsection{NOx}

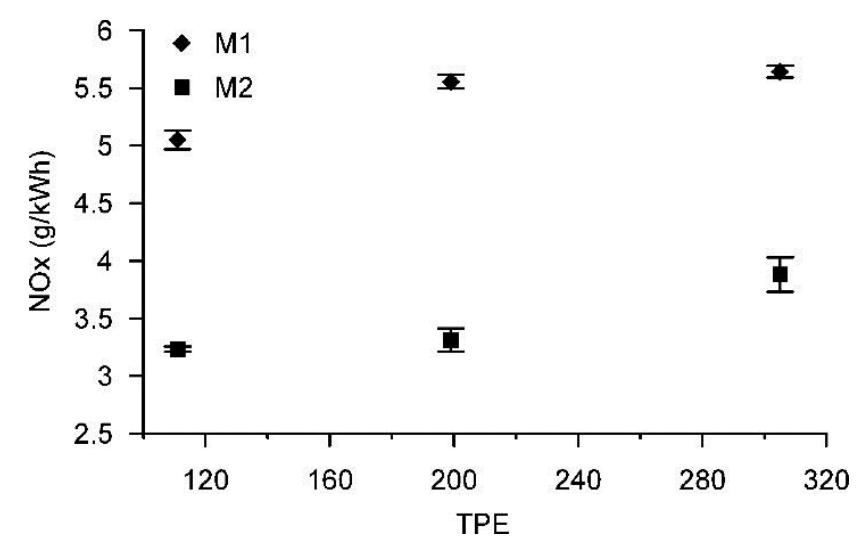

Figure 3 - Specific NOx exhaust emissions of palm oil and linseed oil FAME blends with varying degree of unsaturation (which increases with value TPE, total position equivalent) and at high engine load (M1) and low engine load conditions (M2). Adapted with permission from Benjumea et al. ${ }^{54}$. Copyright 2011 American Chemical Society.

The observed increase in NOx emissions of fatty acid esters, relative to fossil diesel, has been the focus of many studies ${ }^{24,65-69}$, and several of these have also provided insight as to how the composition of varying biodiesels impacts on exhaust NOx emissions. Figure 3 shows the specific NOx exhaust emissions of a four cylinder direct injection turbocharged diesel engine operating on blends of highly unsaturated linseed oil FAME, and relatively more saturated palm oil FAME, and at two engine load and speed conditions ${ }^{54}$. In Figure 3, TPE refers to total position equivalent and is indicative of the FAME blend degree of unsaturation. Benjumea et al. ${ }^{54}$ define TPE as the sum of the allylic position equivalent (APE) index and the bisallylic position equivalent (BAPE), proposed by $\mathrm{Knothe}^{70}$, with a higher TPE value equating to a greater number of carbon to carbon double bonds present in the fatty acid ester alkyl chain and thus a higher degree of unsaturation ${ }^{54}$. At both engine operating conditions (Figure 3), it can 
be seen that levels of specific NOx emissions increase with the degree of FAME fatty acid alkyl chain unsaturation (as indicated by increasing TPE value).

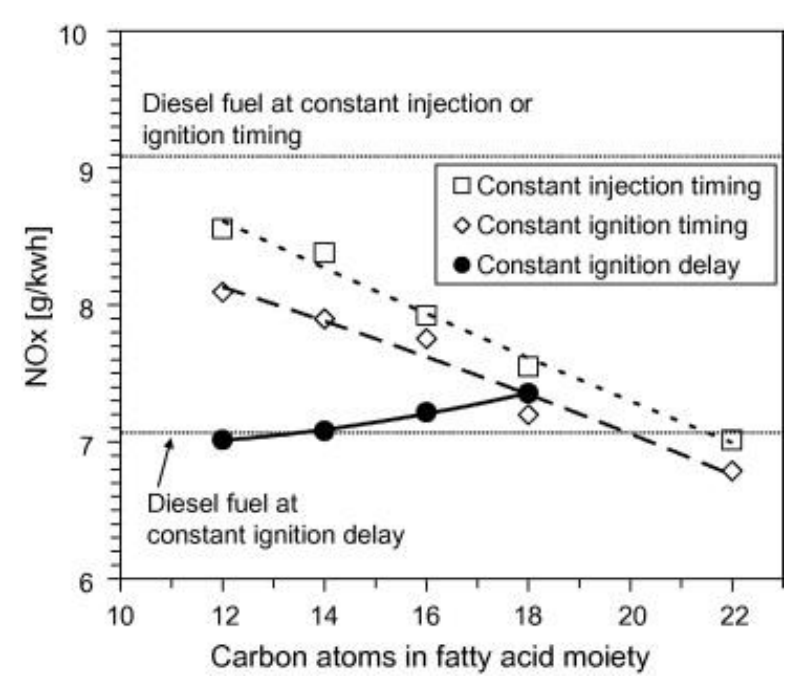

(a)

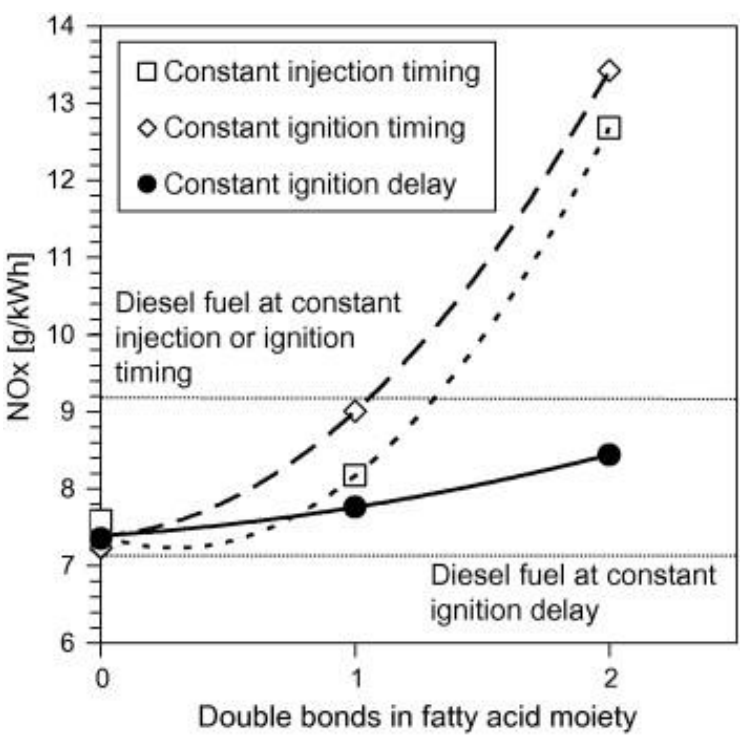

(b)

Figure 4 - Effect of C18 fatty acid methyl ester (a) alkyl chain length and (b) number of double bonds in the alkyl chain on NOx emissions. Adapted from Schönborn et al. ${ }^{52}$ with permission from Elsevier.

Figure 4 shows the effect of increasing the fatty acid methyl ester (FAME) saturated alkyl chain length (C12:0 to $\mathrm{C} 22: 0)$, and increasing the number of double bonds within a constant alkyl chain length (C18:0, C18:1 and C18:2), on NOx emissions in diesel engine tests by Schönborn et al. ${ }^{52}$ of single component fuels. The tests were conducted in a single cylinder direct injection common rail diesel engine at low loads and at constant engine operating conditions (speed and IMEP). The results of tests conducted at three fuel injection timings are shown in Figure 4; two fuel injection timings at which the duration of ignition delay varied according to the fuel (constant injection and constant ignition timing, producing constant in-cylinder physical conditions at the start of injection and start of combustion respectively), and a third injection timing where an ignition improving additive (2 ethylhexyl-nitrate) was utilised to equalise the 
duration of ignition delay for all fuels (resulting in constant in-cylinder physical conditions at both the start of injection and start of combustion).

It can be seen that and constant injection and constant ignition timing increasing the fatty acid alkyl chain length (Figure 4a) decreases NOx emissions, while increasing the number of double bonds present in the fatty acid alkyl chain (Figure 4b) increases NOx emissions (in agreement with studies considering FAME blends from natural oils ${ }^{54}$ ). As discussed in Section 3.1, increasing fatty acid alkyl chain length reduces the duration of ignition delay observed, while increasing the number of double bonds present extends the duration of ignition delay, and peak heat release rates correlate closely with ignition delay ${ }^{52}$. NOx emissions from compression ignition combustion are known to be strongly dependent on in-cylinder temperatures, and the residence time of in-cylinder gases at elevated temperatures, as they are primarily formed by the thermal oxidation of nitrogen ${ }^{69}$ (also known as the extended-Zeldovich mechanism ${ }^{71,72}$ ). It therefore follows that a primary driver of NOx emissions from various biodiesels is the influence of the FAME compositions (fatty acid alkyl chain length and degree of saturation) on the duration of ignition delay and the subsequent in-cylinder temperature conditions that arise from the extent of the premixed burn fraction and the rates of peak heat release ${ }^{52,54}$. Where a change to the fatty acid ester alcohol moiety has influenced the duration of ignition delay, similar observations of NOx emissions correlating with the duration of ignition delay have been $\operatorname{made}^{52,62}$.

In Figures $4 \mathrm{a}$ and $\mathrm{b}$, it is however apparent that at constant ignition delay timing, for which both the start of injection and start of combustion occurred at the same timing (due to the addition of $2 \mathrm{EHN}$ at levels up to $36,942 \mathrm{ppm}^{52}$ ) and thus physical conditions (and patterns of heat release) were constant, NOx emissions increase with both fatty acid alkyl chain length and the number of double bonds present. This is suggestive of a secondary influence of fatty acid ester alkyl chain structure via the adiabatic flame temperature, which increases with both alkyl 
chain length and the degree of unsaturation and potentially increases rates of thermal NOx production $^{52,68,73}$. However, it should be noted that in Figure $4 \mathrm{~b}$, the required dosage levels of $2 \mathrm{EHN}$ (and thus fuel bound nitrogen) to achieve constant ignition delays also increased with fatty acid alkyl chain degree of unsaturation. The addition of fuel bound nitrogen in the form of $2 \mathrm{EHN}$ has been observed to increase NOx emssions ${ }^{74}$, and assuming a fuel flow rate of 250 $\mathrm{g} / \mathrm{kWh}$ in the tests of Schönborn et al. ${ }^{52}$, oxidation of the added 2 EHN nitrogen content would have been sufficient to account for the observed increases in NOx emissions with increasing degree of unsaturation at constant ignition delay timing (Figures $4 b$ ).

A further suggested mechanism by which biodiesel composition influences the formation of NOx is through the level of soot produced during combustion (the drivers of which will be discussed in Section 4.2), and the effects of soot radiative heat transfer in determining incylinder temperatures (and thus rates of thermal NOx production). Mueller et al. ${ }^{68}$ investigated the relative importance of soot radiative heat transfer on tests of FAME derived from soybean oil with an optically accessible heavy duty diesel engine. The FAME doped with phenanthrene to increase soot production exhibited the highest radiative heat transfer, and lower NOx emissions than the non-doped FAME. However, a pure alkane reference fuel exhibited a level of radiative heat transfer between that of the two bio-diesel blends but produced significantly lower NOx emissions than both. Therefore, soot radiative heat transfer is a plausible factor in biodiesel NOx formation $^{68}$, but is likely of lesser importance than the duration of ignition delay and adiabatic flame temperature ${ }^{52}$. 


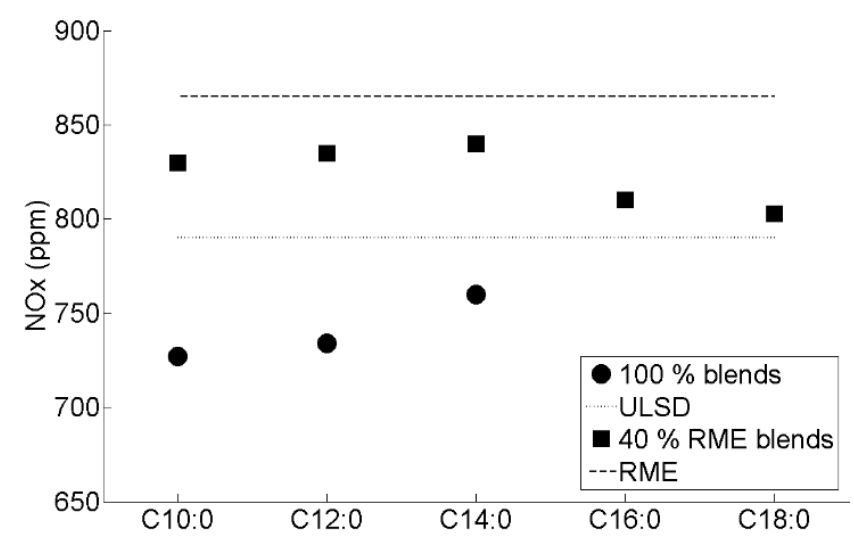

Figure 5 - NOx exhaust emissions with $0 \%$ EGR and increasing fatty acid ester alkyl chain length, as single component fuels and as $40 \% \mathrm{v} / \mathrm{v}$ rapeseed methyl ester (RME). Redrawn from Pinzi at al. ${ }^{75}$ with permission from Elsevier.

Figure 5 shows the NOx emissions of fully saturated fatty acid esters as single component fuels and as $40 \% \mathrm{v} / \mathrm{v}$ blends with rapeseed oil FAME, tested in a direct injection compression ignition engine with a mechanically actuated fuel injector ${ }^{75}$. In Figure 5, it can be seen that NOx emissions increase with increasing fatty acid alkyl chain length from C10:0 to C14:0. This is contrary to studies of similar single component FAMEs in a direct injection common rail compression ignition engine ${ }^{52}$, where NOx emissions were observed to decrease with increasing fatty acid alkyl chain length (Figure 4a). This coincides with an increasing bulk modulus of the fatty acid esters with alkyl chain length and degree of unsaturation ${ }^{75}$, which in mechanical injection systems results in an effective advance in the fuel injection timing ${ }^{76}$. Therefore in Figure 5, the increase in NOx emissions observed when considering pure methyl esters of carbon chain lengths of between C10:0 and C14:0 can be attributed to an increasingly advanced injection timing, which results in an earlier start of combustion and a longer residence time of in-cylinder gases at the high temperature conditions necessary for NOx formation. 


\subsection{Particulate matter}

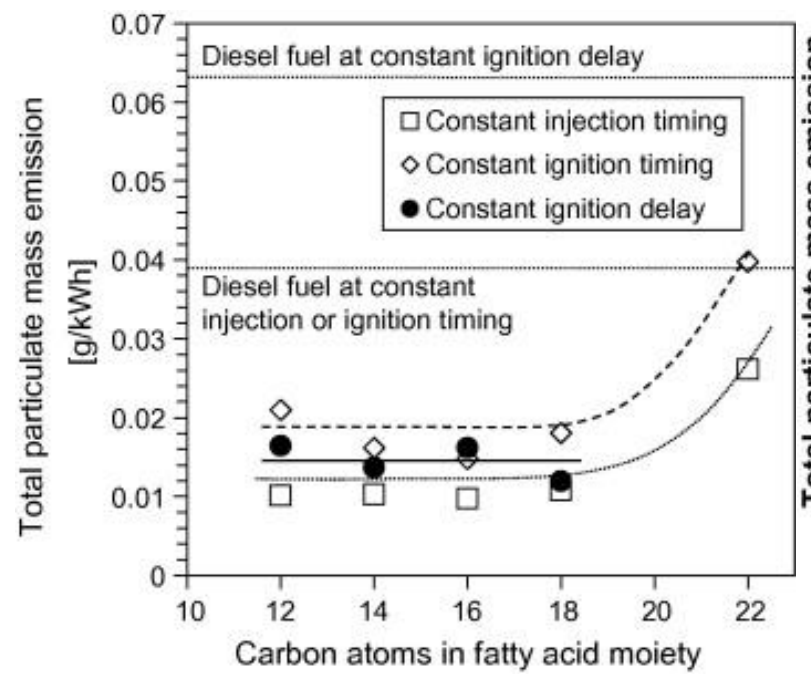

(a)

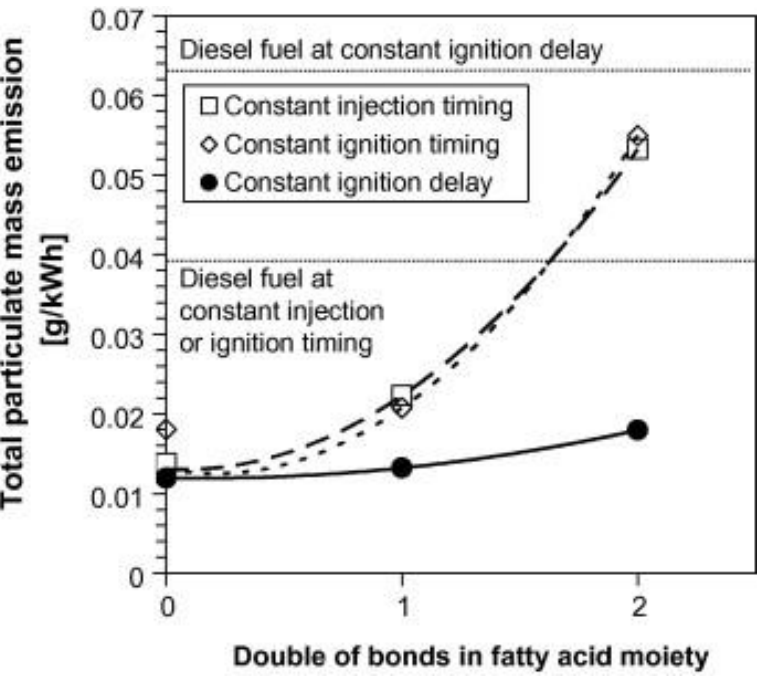

(b)

Figure 6 - Effect of C18 fatty acid methyl ester (a) alkyl chain length and (b) number of double bonds in the alkyl chain on total particulate mass emissions. Adapted from Schönborn et al. ${ }^{52}$ with permission from Elsevier.

The emission of particulate matter (PM) from various biodiesels has received less attention than that of NOx, however, several studies have observed an influence of FAME composition on the total mass of particulates emitted during compression ignition combustion ${ }^{52,53,62}$. Figure 5 shows the effect of increasing the FAME saturated alkyl chain length and increasing the number of double bonds within a constant alkyl chain length on total particulate mass emissions in the engine tests of single component fuels by Schönborn et al. ${ }^{52}$. At all three injection timings, it can be seen that between fatty acid alkyl chain lengths of 12 and 18 (C12:0 to C18:0), there is no clearly discernible impact on emissions of particulate matter total mass, with only the C22 ester emitting significantly higher levels of particulate matter (Figure 6a). It was suggested that this may be attributable to the reduced oxygen content and higher viscosity of the $\mathrm{C} 22$ ester relative to the esters of shorter fatty acid alkyl chain length, as these properties may reduce the level of oxygen available for soot oxidation and impede the efficiency of fuel 
and air mixing respectively. Formation of soot in compression ignition combustion is known to occur predominately in fuel rich areas of the in-cylinder charge, such as are present during diffusion controlled combustion ${ }^{77}$, where insufficient oxygen is available for complete fuel oxidation and pyrolysis reactions occur instead ${ }^{78}$.

In Figure $6 b$, it can be seen that increasing the number of double bonds within the fatty acid ester alkyl chain increases the level of particulate matter emitted at all injection timings. The presence of double bonds within fatty acid ester alkyl chains has been suggested as increasing the formation of soot precursors and thus total levels of particulate matter emitted ${ }^{52}$. However, in engine and tube reactor test utilising a carbon-13 isotope labelling technique to identify the contribution of individual carbon atoms within a fuel molecule to emissions of particulate matter, Eveleigh et al. ${ }^{79}$ found the double bonded carbon atoms within the fatty acid alkyl chain of oleic acid (C18:1) to convert to PM at approximately the same rate as single bonded carbon atoms within the fuel molecule.

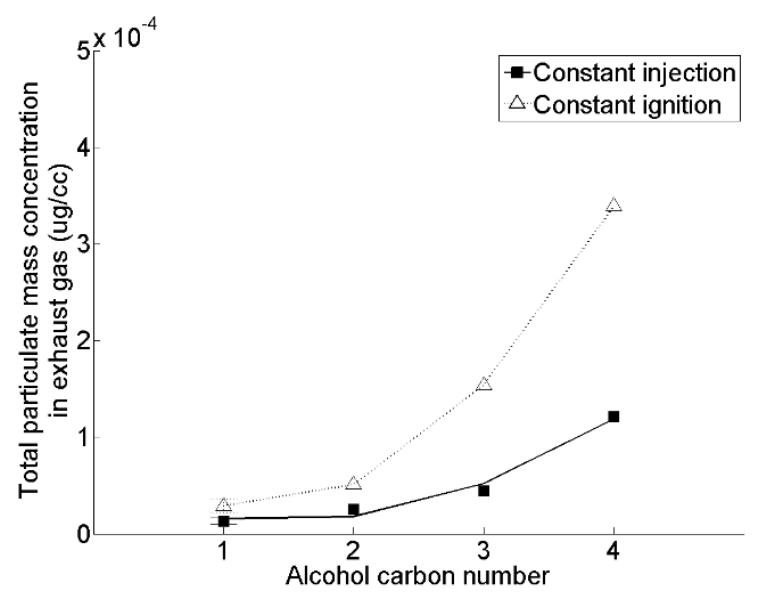

Figure 7 - Effect of C18 fatty acid saturated ester alcohol moiety straight carbon chain length on total particulate mass emissions. Adapted with permission from Hellier et al. ${ }^{62}$. Copyright 2012 American Chemical Society. 
Figure 7 shows the effect of increasing the straight carbon chain length of the alcohol moiety of a saturated fatty acid ester (C18:0) on the emission of total particulate matter mass ${ }^{62}$. While no clear influence of substituting the methyl alcohol moiety of the fatty acid ester with ethyl, propyl and butyl alcohol moieties on the duration of fuel ignition delay was observed ${ }^{62}$, it can be seen that an increase in the fatty acid ester alcohol moiety results in a significant increase in the production of particulate matter (Figure 7). As observed in the increase of the fatty acid moiety alkyl chain length (Figure 6a), the increase of alcohol moiety length coincides with a decreasing molecular oxygen content and increasing viscosities and boiling points ${ }^{62}$. A saturated C18 fatty acid iso-butyl ester was also tested under the same conditions as the results presented in Figure 7, and found to emit levels of particulate matter similar to those observed from the equivalent $n$-propyl ester ${ }^{62}$. Furthermore, the influence of the alcohol moiety on total particulate mass emissions was found to be of much greater significance than that of removing the ester functional group completely (as observed through testing of $n$-octadecane under the same conditions $)^{62}$.

In the case of direct mechanical fuel injection, while increasing fatty acid alkyl chain length has been observed to increase PM emissions, increasing the degree of unsaturation results in decreased PM emissions ${ }^{53}$. As fatty acid ester viscosity and melting point both increase with increasing degree of saturation, it was suggested that these factors may be more significant in detrimentally affecting fuel and air mixing at mechanical injection pressures which are generally lower than in common rail injection systems ( $180 \mathrm{bar}^{53}$ versus $450 \mathrm{bar}^{52}$ in the studies cited). Pinzi et al. ${ }^{53}$ further suggested that the varying oxygen content of FAME with increasing or decreasing alkyl length may be the primary driver in determining PM emissions from biodiesel, as the presence of fuel bound oxygen may prevent the fuel pyrolysis reactions that initiate PM formation ${ }^{80}$. However, it was found by Eveleigh et al. ${ }^{79}$ that the carbon atom bonded to both oxygen atoms in methyl oleate (C18:1), and also oleic acid, does not contribute to the 
formation of PM, suggesting that the carbon oxygen bonds are not broken during combustion (and so the carbon atom is unavailable for the formation of soot). It has therefore been speculated that the oxygen present in FAME also remains bonded to the carbon atoms to which they are originally attached, and thus are not available to prevent the pyrolytic breakdown of the remaining elements of the fuel molecule ${ }^{79,81}$.

\section{Conclusions and future renewable diesel fuels}

Biodiesel is an important renewable alternative to fossil diesel for use in compression ignition combustion. Many different feedstocks are available for the production of biodiesel, and with regards to the varying composition of these the following conclusions as to the impact on compression ignition combustion and emissions characteristics can be drawn:

1. There is significant variation in the fatty acid profile of the oils from food crops most widely utilised at present for biodiesel production. Furthermore, oils from non-edible and potentially more sustainable sources, such as micro-organisms, exhibit similar fatty acid profiles, suggesting that they are viable biodiesel feedstocks.

2. The primary influence on combustion phasing of the fatty acid moiety of fatty acid esters is through the alkyl chain length and degree of saturation. An increased alkyl chain length or degree of saturation reduces the duration of ignition delay, as an increase in either feature increases the rates of the low temperature branching reactions which result in autoignition.

3. An increase in the fatty acid ester alcohol moiety alkyl chain length can reduce the duration of ignition delay, while the presence of carbon chain branches in the alcohol moiety can increase the duration ignition. However, the impact of the alcohol moiety on ignition delay is 
less than the fatty acid moiety, and so where a specific ignition delay of a biodiesel is required, this is best achieved through modification of the fatty acid profile.

4. In direct injection common rail compression ignition combustion, the primary influence of the biodiesel composition on the levels of NOx emitted is through the duration of ignition delay. Longer ignition delays result in a larger premixed burn fraction and peak heat release rates, which increase the rates of thermal NOx production. In mechanically actuated fuel injection, biodiesel bulk modulus, which increases with alkyl chain length and degree of unsaturation, has a significant influence on the time at which fuel injection commences and thus the residence time of in-cylinder gases at elevated temperatures at which NOx formation occurs. Therefore, it be may be advantageous to utilise different biodiesels of compositions optimised for lower NOx emissions in common rail and mechanical fuel systems respectively.

5. Emissions of PM from biodiesel appear most clearly influenced by physical properties, such as viscosity and boiling point, which reduce the efficiency of fuel and air mixing. These properties increase with increasing carbon chain of either the fatty acid or alcohol moieties. Therefore, for the use of longer chain length alcohols than methanol in biodiesel production, it may be helpful to select oils of short fatty acid alkyl chain length so that emissions of PM are significantly increased.

While biodiesel is likely to remain the most significant contributor to the displacement of fossil-derived diesels, there are a number of renewable potential fuels for compression ignition engines that are of increasing interest. An alternative route for the modification of vegetable oils are processes such as decarboxylation and hydrodecarboxylation which remove the oxygenated functional group (and also saturate carbon double bonds in the case of hydrodecarboxylation), producing long chain alkanes and alkenes ${ }^{82,83}$. The products of such processes are commonly referred to as hydrotreated vegetable oils (HVO), and renewable or 
green diesel ${ }^{82}$ and is receiving significant commercial interest ${ }^{84}$. Biomass to liquid (BTL) processes, which involve the gasification of biomass and subsequent upgrading to larger molecules through the Fischer-Tropsch process, can also produce alkanes and alkenes in a range suitable for compression ignition combustion ${ }^{85}$. There is also potential for the catalytic upgrading of short chain alcohols to larger molecules ${ }^{86}$, possibly with utilisation of $\mathrm{CO}_{2}$ as a feedstock ${ }^{87}$, producing oxygenated fuel molecules such as ketones or carbonate esters. A further exciting possibility is the use of synthetic biology to genetically engineer microorganisms, such as micro-algae, to produce designer fuels (for example terpenes) with molecular structures optimised for improved combustion and emissions characteristics ${ }^{88}$.

\section{Acknowledgements}

The authors wish to thank the UK Engineering and Physical Science Research Council (EPSRC) for financial support.

\section{Nomenclature}

NOx - nitrogen oxides

GHG - greenhouse gases

FAME - fatty acid methyl ester

PM - particulate matter

CFR - cooperative fuels research

TPE - total position equivalent

HVO - hydrotreated vegetable oil

BTL - biomass to liquid

$\mathrm{CO}_{2}$ - carbon dioxide

Moiety - molecule subsection or functional group 


\section{References}

1. BP Global Fuels. BP Energy Outlook 2014 - 2035 [Internet]. 2014;

2. Intergovernmental Panel on Climate Change. Intergovernmental Panel on Climate Change 2014: Impacts, Adaption and Vulnerability [Internet]. 2014 [cited 2014 Apr 24].

3. Newman P. Beyond Peak Oil: Will Our Cities Collapse? J Urban Technol [Internet]. 2007;14(2):15-30.

4. Verbruggen A, Al Marchohi M. Views on peak oil and its relation to climate change policy. Energy Policy [Internet]. 2010 Oct;38(10):5572-5581.

5. Mcglade C, Ekins P. The geographical distribution of fossil fuels unused when limiting global warming to $2{ }^{\circ} \mathrm{C}$. Nature [Internet]. 2014 Jan 7;517(7533):187-190.

6. Sanchez Fernandez E, Goetheer EL V, Manzolini G, Macchi E, Rezvani S, Vlugt TJH. Thermodynamic assessment of amine based $\mathrm{CO} 2$ capture technologies in power plants based on European Benchmarking Task Force methodology. Fuel [Internet]. 2014 Apr;129:318-329.

7. CRUZ JM, Ogunlowo AS, Chancellor WJ, Goss JR. Vegetable oils as fuels for diesel engines. Resour Conserv [Internet]. 1981;6(1):69-74.

8. Pryde EH. Vegetable oils as diesel fuels: Overview. J Am Oil Chem Soc [Internet]. $1983 ; 60(8): 1557-1558$.

9. Ryan TW, Dodge LG, Callahan TJ. The effects of vegetable oil properties on injection and combustion in two different diesel engines. J Am Oil Chem Soc [Internet]. 1984;61(10):1610-1619.

10. Harrington KJ. Chemical and physical properties of vegetable oil esters and their effect on diesel fuel performance. Biomass [Internet]. 1986;9(1):1-17.

11. Graboski MS, McCormick RL. Combustion of fat and vegetable oil derived fuels in diesel engines. Prog Energy Combust Sci. 1998;24(2):125-164.

12. Ma F, Hanna MA. Biodiesel production: a review. Bioresour Technol. 1999;70(1):115.

13. Leung DYC, Wu X, Leung MKH. A review on biodiesel production using catalyzed transesterification. Appl Energy [Internet]. 2010 Apr;87(4):1083-1095.

14. Vyas AP, Verma JL, Subrahmanyam N. A review on FAME production processes. Fuel. 2010;89(1):1-9. 
15. Geuens J, Kremsner JM, Nebel BA, Schober S, Dommisse RA, Mittelbach M, et al. Microwave-Assisted Catalyst-Free Transesterification of Triglycerides with 1-Butanol under Supercritical Conditions. Energy Fuels. 2008;22(1):643-645.

16. Muppaneni T, Reddy HK, Ponnusamy S, Patil PD, Sun Y, Dailey P, et al. Optimization of biodiesel production from palm oil under supercritical ethanol conditions using hexane as co-solvent: A response surface methodology approach. Fuel. 2013;107(0):633-640.

17. European Commission, European Parliament and Council. Directive 2009/28/EC of the European Parliament and of the Council of 23 April 2009 on the promotion of the use of energy from renewable sources and amending and subsequently repealing Directives 2001/77/EC and 2003/30/EC (Text with EEA relevance). Off J Eur Union [Internet]. 2009;16-62.

18. Overmars KP, Stehfest E, Ros JPM, Prins AG. Indirect land use change emissions related to EU biofuel consumption: An analysis based on historical data. Environ Sci Policy. 2011;14:248-257.

19. European Commission. Proposal for a DIRECTIVE OF THE EUROPEAN PARLIAMENT AND OF THE COUNCIL amending Directive 98/70/EC relating to the quality of petrol and diesel fuels and amending Directive 2009/28/EC on the promotion of the use of energy from renewable sources (Text [Internet]. 2012;/0288.

20. Knothe G. Analysis of oxidized biodiesel by $1 \mathrm{H}-\mathrm{NMR}$ and effect of contact area with air. Eur J Lipid Sci Technol [Internet]. 2006 Jun;108(6):493-500.

21. Bannister CD, Chuck CJ, Bounds M, Hawley JG. Oxidative Stability of Biodiesel Fuel. Proc Inst Mech Eng Part D J Automob Eng. 2011;225(1):99-114.

22. Basha SA, Gopal KR, Jebaraj S. A review on biodiesel production, combustion, emissions and performance. Renew Sustain Energy Rev [Internet]. 2009 Sep;13(67):1628-1634.

23. Szybist JP, Song J, Alam M, Boehman AL. Biodiesel combustion, emissions and emission control. Fuel Process Technol. 2007;88(7):679-691.

24. Hoekman SK, Robbins C. Review of the effects of biodiesel on NOx emissions. Fuel Process. Technol. 2012;96:237-249.

25. Atadashi IM, Aroua MK, Aziz AA. High quality biodiesel and its diesel engine application: A review. Renew Sustain Energy Rev [Internet]. 2010;14(7):1999-2008.

26. Lapuerta M, Armas O, Rodríguez-Fernández J. Effect of biodiesel fuels on diesel engine emissions. Prog Energy Combust Sci [Internet]. 2008 Apr;34(2):198-223.

27. Hoekman SK, Broch A, Robbins C, Ceniceros E, Natarajan M. Review of biodiesel composition, properties, and specifications. Renew Sustain Energy Rev [Internet]. 2012;16(1):143-169. 
28. Schwab AW, Bagby MO, Freedman B. Preparation and properties of diesel fuels from vegetable oils. Fuel. 1987;66(10):1372-1378.

29. European Biodiesel Board. 2009-2010: EU biodiesel industry restrained growth in challenging times [Internet]. 2010;

30. Singh SP, Singh D. Biodiesel production through the use of different sources and characterization of oils and their esters as the substitute of diesel: A review. Renew Sustain Energy Rev [Internet]. 2010;14(1):200-216.

31. Rakopoulos DC. Combustion and emissions of cottonseed oil and its bio-diesel in blends with either n-butanol or diethyl ether in HSDI diesel engine. Fuel. (0).

32. Benjumea P, Agudelo J, Agudelo A. Effect of altitude and palm oil biodiesel fuelling on the performance and combustion characteristics of a HSDI diesel engine. Fuel. 2009;88(4):725-731.

33. Nguyen T, Do L, Sabatini DA. Biodiesel production via peanut oil extraction using diesel-based reverse-micellar microemulsions. Fuel. 2010;89(9):2285-2291.

34. Bryan R. Preparation of fatty acid methyl esters from hazelnut, high-oleic peanut and walnut oils and evaluation as biodiesel. Fuel. 2012;92(1):231-238.

35. Atabani AE, Silitonga AS, Ong HC, Mahlia TMI, Masjuki HH, Badruddin IA, et al. Non-edible vegetable oils: A critical evaluation of oil extraction, fatty acid compositions, biodiesel production, characteristics, engine performance and emissions production. Renew Sustain Energy Rev [Internet]. 2013 Feb;18:211-245.

36. Hellier P, Ladommatos N, Yusaf T. The influence of straight vegetable oil fatty acid composition on compression ignition combustion and emissions. FUEL [Internet]. 2015 Nov;143:131-143.

37. Vicente G, Bautista LF, Rodríguez R, Gutiérrez FJ, Sádaba I, Ruiz-Vázquez RM, et al. Biodiesel production from biomass of an oleaginous fungus. Biochem Eng J [Internet]. 2009;48(1):22-27.

38. Munch G, Sestric R, Sparling R, Levin DB, Cicek N. Lipid production in the undercharacterized oleaginous yeasts, Rhodosporidium babjevae and Rhodosporidium diobovatum, from biodiesel-derived waste glycerol. Bioresour Technol [Internet]. 2015 Jun;185:49-55.

39. Jain S, Sharma MP. Oxidation stability of blends of Jatropha biodiesel with diesel. Fuel. 2011;90(10):3014-3020.

40. Oliveira JF, Lucena IL, Saboya RMA, Rodrigues ML, Torres AE, Fernandes FAN, et al. Biodiesel production from waste coconut oil by esterification with ethanol: The effect of water removal by adsorption. Renew Energy. 2010;35(11):2581-2584. 
41. Veljković VB, Lakićević SH, Stamenković OS, Todorović ZB, Lazić ML. Biodiesel production from tobacco (Nicotiana tabacum L.) seed oil with a high content of free fatty acids. Fuel [Internet]. 2006 Dec;85(17-18):2671-2675.

42. Pinzi S, Garcia IL, Lopez-Gimenez FJ, de Castro MDL, Dorado G, Dorado MP. The Ideal Vegetable Oil-based Biodiesel Composition: A Review of Social, Economical and Technical Implications. Energy Fuels. 2000;0(0).

43. Shay EG. Diesel fuel from vegetable oils: Status and opportunities. Biomass and Bioenergy. 1993;4(4):227-242.

44. Lapuerta M, Herreros JM, Lyons LL, García-Contreras R, Briceño Y. Effect of the alcohol type used in the production of waste cooking oil biodiesel on diesel performance and emissions. Fuel [Internet]. 2008 Nov;87(15-16):3161-3169.

45. Xue J. Combustion characteristics, engine performances and emissions of waste edible oil biodiesel in diesel engine. Renew Sustain Energy Rev [Internet]. 2013 Jul;23:350365.

46. Vardon DR, Moser BR, Zheng W, Witkin K, Evangelista RL, Strathmann TJ, et al. Complete utilization of spent coffee grounds to produce biodiesel, bio-oil, and biochar. ACS Sustain Chem Eng. 2013;1:1286-1294.

47. Bastianoni S, Coppola F, Tiezzi E, Colacevich A, Borghini F, Focardi S. Biofuel potential production from the Orbetello lagoon macroalgae: A comparison with sunflower feedstock. Biomass and Bioenergy. 2008;32(7):619-628.

48. Zhao B, Su Y. Process effect of microalgal-carbon dioxide fixation and biomass production: A review. Renew Sustain Energy Rev [Internet]. 2014 Mar;31:121-132.

49. Griffiths MJ, van Hille RP, Harrison STL. Lipid productivity, settling potential and fatty acid profile of 11 microalgal species grown under nitrogen replete and limited conditions. J Appl Phycol. 2012;24(5):989-1001.

50. Bittle JA, Knight BM, Jacobs TJ. Interesting behavior of biodiesel ignition delay and combustion duration. Energy and Fuels [Internet]. 2010;24(8):4166-4177.

51. Knothe G. A comprehensive evaluation of the cetane numbers of fatty acid methyl esters. Fuel [Internet]. 2014;119:6-13.

52. Schönborn A, Ladommatos N, Williams J, Allan R, Rogerson J. The influence of molecular structure of fatty acid monoalkyl esters on diesel combustion. Combust Flame [Internet]. $2009 \mathrm{Jul} ; 156(7): 1396-1412$.

53. Allen C, Toulson E, Tepe D, Schock H, Miller D, Lee T. Characterization of the effect of fatty ester composition on the ignition behavior of biodiesel fuel sprays. Fuel [Internet]. 2013 Sep;111(0):659-669. 
54. Benjumea P, Agudelo JR, Agudelo AF. Effect of the degree of unsaturation of biodiesel fuels on engine performance, combustion characteristics, and emissions. Energy and Fuels [Internet]. 2011 Jan 20;25(1):77-85.

55. Zhang Y, Yang Y, Boehman AL. Premixed ignition behavior of C9 fatty acid esters: A motored engine study. Combust Flame. 2009;156(6):1202-1213.

56. Zhang Y, Boehman AL. Experimental study of the autoignition of C8H16O2 ethyl and methyl esters in a motored engine. Combust Flame. 2010;157(3):546-555.

57. Hellier P, Ladommatos N, Allan R, Payne M, Rogerson J. The Impact of Saturated and Unsaturated Fuel Molecules on Diesel Combustion and Exhaust Emissions. SAE Int J Fuels Lubr [Internet]. 2011 Aug;5(1):106-122.

58. Westbrook CK. Chemical kinetics of hydrocarbon ignition in practical combustion systems. Proc Combust Inst. 2000;28(2):1563-1577.

59. Mehl M, Pitz WJ, Westbrook CK, Yasunaga K, Conroy C, Curran HJ. Autoignition behavior of unsaturated hydrocarbons in the low and high temperature regions. Proc Combust Inst. 2011;33(1):201-208.

60. Knothe G, Bagby M, Ryan TW. Cetane Numbers of Fatty Compounds: Influence of Compound Structure of Various Potential Cetane Improvers. SAE Tech Pap Ser. 1997;(971681).

61. Serdari A, Lois E, Stournas S. Impact of Esters of Mono- and Dicarboxylic Acids on Diesel Fuel Quality. Ind Eng Chem Res. 1999 Sep;38(9):3543-3548.

62. Hellier P, Ladommatos N, Allan R, Rogerson J. The influence of fatty acid ester alcohol moiety molecular structure on diesel combustion and emissions. Energy and Fuels [Internet]. 2012 Mar 15;26(3):1912-1927.

63. Knothe G, Matheaus AC, Ryan TW. Cetane numbers of branched and straight-chain fatty esters determined in an ignition quality tester. Fuel. 2003;82(8):971-975.

64. Kinoshita E. Combustion Characteristics of a DI Diesel Engine with Palm Oil Butyl and Isobutyl Esters. JSAE Powertrains, Fuels Lubr Meet. 2011;(2011-01-1937):460466.

65. Szybist JP, Boehman AL, Taylor JD, McCormick RL. Evaluation of formulation strategies to eliminate the biodiesel NOx effect. Fuel Process Technol. 2005;86(10):1109-1126.

66. Mccormick RL, Alvarez JR, Graboski MS, Tyson KS, Vertin K. Fuel Additive and Blending Approaches to Reducing NOx Emissions from Biodiesel. 2002 May;(x).

67. Agarwal D, Sinha S, Agarwal AK. Experimental investigation of control of NOx emissions in biodiesel-fueled compression ignition engine. Renew Energy [Internet]. 2006 Nov;31(14):2356-2369. 
68. Mueller CJ, Boehman AL, Martin GC. An Experimental Investigation of the Origin of Increased NOx Emissions When Fueling a Heavy-Duty Compression-Ignition Engine with Soy Biodiesel. SAE Tech Pap Ser. 2009;1792-2009.

69. Ban-Weiss GA, Chen JY, Buchholz BA, Dibble RW. A numerical investigation into the anomalous slight NOx increase when burning biodiesel; A new (old) theory. Fuel Process Technol. 2007;88(7):659-667.

70. Knothe G. Structure indices in FA chemistry. How relevant is the iodine value? [Internet]. J. Am. Oil Chem. Soc. 2002 Sep;79(9):847-854.

71. Zeldovich Y. B, Sadavnikov PY, Frank-Kamentskii DA. Oxidation of Nitrogen in Combustion. Acad Sci USSR, Moscow. 1947;

72. LAVOIE GA, HEYWOOD JB, KECK JC. Experimental and Theoretical Study of Nitric Oxide Formation in Internal Combustion Engines. Combust. Sci. Technol. 1970;1(4):313-326.

73. Hellier P, Ladommatos N, Allan R, Filip S, Rogerson J. The importance of double bond position and cis-trans isomerisation in diesel combustion and emissions. Fuel [Internet]. 2013 Mar;105:477-489.

74. Ickes AM, Bohac S V, Assanis DN. Effect of 2-Ethylhexyl Nitrate Cetane Improver on NOx Emissions from Premixed Low-Temperature Diesel Combustion. Energy Fuels. 2009;23(10):4943-4948.

75. Pinzi S, Rounce P, Herreros JM, Tsolakis A, Pilar Dorado M. The effect of biodiesel fatty acid composition on combustion and diesel engine exhaust emissions. Fuel [Internet]. 2013 Feb;104:170-182.

76. Boehman L, Morris D, Szybist J. The Impact of the Bulk Modulus of Diesel Fuels on Fuel Injection Timing. Energy \& Fuels. 2004;18(6):1877-1882.

77. Dec JE. A Conceptual Model of DI Diesel Injection Based on Laser-Sheet Imaging. SAE Tech Pap Ser. 1997;970873.

78. Tree DR, Svensson KI. Soot processes in compression ignition engines. Prog Energy Combust Sci. 2007;33(3):272-309.

79. Eveleigh A, Ladommatos N, Hellier P, Jourdan A-L. An investigation into the conversion of specific carbon atoms in oleic acid and methyl oleate to particulate matter in a diesel engine and tube reactor. Fuel [Internet]. 2015;153:604-611.

80. Lapuerta M, Armas O, Rodr guez-Fernbndez J. Effect of biodiesel fuels on diesel engine emissions. Prog Energy Combust Sci. 2008;34(2):198-223.

81. Buchholz BA, Mueller CJ, Upatnieks A, Martin GC, Pitz WJ, Westbrook CK. Using Carbon-14 Isotope Tracing to Investigate Molecular Structure Effects of the Oxygenate Dibutyl Maleate on Soot Emissions from a DI Diesel Engine. SAE Tech Pap Ser. 2004;1849-2004. 
82. No SY. Application of hydrotreated vegetable oil from triglyceride based biomass to CI engines - A review [Internet]. Fuel. 2014;115:88-96.

83. Knothe G. Biodiesel and renewable diesel: A comparison. Prog Energy Combust Sci. 2010;36(3):364-373.

84. UOP's Green Diesel to be produced from bio feedstocks in US plant. Focus Catal [Internet]. $2012 \mathrm{Jul} ; 2012(7): 4$.

85. Van Steen E, Claeys M. Fischer-Tropsch Catalysts for the Biomass-to-Liquid (BTL)Process. Chem Eng Technol [Internet]. 2008;31(5):655-666.

86. Anbarasan P, Baer ZC, Sreekumar S, Gross E, Binder JB, Blanch HW, et al. Integration of chemical catalysis with extractive fermentation to produce fuels. Nature [Internet]. 2012 Nov 8;491(7423):235-9.

87. Hellier P, Ladommatos N, Allan R, Rogerson J. Influence of Carbonate Ester Molecular Structure on Compression Ignition Combustion and Emissions. Energy \& Fuels [Internet]. 2013 Aug 25;27(9):130825122743008.

88. Hellier P, Al-Haj L, Talibi M, Purton S, Ladommatos N. Combustion and emissions characterization of terpenes with a view to their biological production in cyanobacteria. Fuel [Internet]. 2013;111:670-688. 